\title{
Corn Cropping System And Nitrogen Fertilizers Technologies Affect Ammonia Volatilization In Brazilian Tropical Soils
}

\section{César Ferreira Santos}

Federal University of Lavras

Sheila Isabel do Carmo Pinto

Federal Institute of Minas Gerais

Douglas Guelfi ( $\sim$ douglasguelfi@ufla.br )

Federal University of Lavras

\section{Sara Dantas Rosa}

University of Brasilia

\section{Adrianne Braga da Fonseca}

Federal University of Lavras

\section{Tales Jesus Fernandes}

Federal University of Lavras

\section{Renato Avelar Ferreira}

Federal Institute of Minas Gerais

\section{Leandro Barbosa Satil}

Federal Institute of Minas Gerais

Ana Paula Pereira Nunes

Federal University of Lavras

Konrad Passos e Silva

Federal Institute of Minas Gerais

\section{Research Article}

Keywords: no-till, urea technologies, nitrogen use efficiency, urease inhibitors

Posted Date: November 17th, 2021

DOl: https://doi.org/10.21203/rs.3.rs-1051385/v1

License: () (1) This work is licensed under a Creative Commons Attribution 4.0 International License. Read Full License 


\section{Abstract}

With the advance of the no-tillage system (NT system) in Brazil, the adoption of technologies for nitrogen fertilization in these soils become essential for increasing the efficiency of $\mathrm{N}$ use in the system. In this sense, the objective of this study was to quantify ammonia losses, $\mathrm{N}$ removal in grains, and with 2nd crop yield in NT system and conventional (T system) planting areas that received application of different N fertilizers and their technologies. Ammonia volatilization, $\mathrm{N}$ extraction in grains and corn yield in response to the application of conventional fertilizers were compared to urease inhibitors treated urea in NT and T systems. The treatments were: no-N (Control); Prilled urea $(\mathrm{PU})$; urea + NBPT $\left(\mathrm{U}_{\mathrm{NBPT}}\right)$; urea + $\mathrm{Cu}+\mathrm{B}\left(\mathrm{U}_{\mathrm{CuB}}\right)$; ammonium nitrate (AN), and ammonium sulfate (AS). In the NT system, the $\mathrm{N}^{-\mathrm{NH}_{3}}$ losses were $49 \%$ greater than in the T system; without differences for corn yield. The fertilizers as AN, and AS had the lowest $\mathrm{N}^{-\mathrm{NH}_{3}}$ losses, regardless of tillage system. $\mathrm{U}_{\mathrm{NBPT}}$ reduced the mean $\mathrm{N}^{-\mathrm{NH}_{3}}$ loss by $33 \%$ compared to PU. $U_{\mathrm{NBPT}}$ $\left(1,200 \mathrm{mg} \mathrm{kg}^{-1}\right)$ and $\mathrm{U}_{\mathrm{NBPT}}\left(180 \mathrm{mg} \mathrm{kg}^{-1}\right)$ reduced by $72 \%$ and $22 \%$ the $\mathrm{N}-\mathrm{NH}_{3}$ losses compared to $\mathrm{PU}$ in the NT system.

\section{Introduction}

Among the nutrients most used in the fertilization of corn, nitrogen $(\mathrm{N})$ stands out as it is required in large amounts. It is estimated that $286 \mathrm{~kg} \mathrm{~N}$ are required for a corn yield of $12 \mathrm{Mg} \mathrm{ha}^{-1}$, which is the average corn yield in the Brazilian production areas ${ }^{1}$. Urea is the $\mathrm{N}$-fertilizer source most used in corn production systems in Brazil, with values corresponding to $60 \%$ of the $\mathrm{N}$ used in Brazilian agriculture. However, the agronomic efficiency of conventional urea applied without incorporation is low owing to the losses of $\mathrm{N}^{-\mathrm{NH}_{3}}$ by volatilization with negative impacts to the environment ${ }^{2,3,4}$. Aligned with worldwide trends, initiatives or guidelines related to the mitigation of $\mathrm{N}-\mathrm{NH}_{3}$ losses from $\mathrm{N}$-fertilizers, such as conventional urea, may also increase in Brazil ${ }^{5,6}$.

The $\mathrm{N}-\mathrm{NH}_{3}$ losses are higher with the use of urea without any kind of technologies, and are intensified by soil and climate conditions such as $\mathrm{pH}, \mathrm{CEC}$, humidity, temperature and level of urease activity in the soil, relative air humidity, rainfall, and presence of crop residues on the soil7,8,9. Considering the typical tropical conditions in Brazil, these losses can be aggravated with average losses of $\mathrm{N}-\mathrm{NH}_{3}$ around $30 \%$ in the varied cultivation systems ${ }^{4,10,11}$.

Besides the propitious conditions of the tropical climate, the increase in the number of areas cultivated with corn under no-till (NT system) is another key factor that favors the ${\mathrm{N}-\mathrm{NH}_{3}}_{3}$ losses. The areas under NT system have increased in Brazil due to the NT system advantages, such as increased organic matter content, reduced losses of soil and nutrients by erosion, and increased maintenance of soil moisture ${ }^{12,13}$. On the other side, in NT systems the presence of straw on the soil surface intensifies the $\mathrm{N}^{-\mathrm{NH}_{3}}$ losses, particularly with the application of urea ${ }^{14}$, being $25 \%$ greater than the $\mathrm{N}^{-\mathrm{NH}_{3}}$ losses in conventional tillage systems (T system $)^{3}$. The increase in soil organic matter content enhances the activity of urease, enzyme 
that operates in the hydrolysis of urea into $\mathrm{N}-\mathrm{NH}_{3}$ and $\mathrm{CO}_{2}{ }^{15,14}$. Moreover, the straw prevents the direct contact between the fertilizer and the soil, reducing its incorporation by the rainwater ${ }^{2,7}$.

Ammonia volatilization cause decline in $\mathrm{N}$ retention in soils or soil fertility, grain yield and $\mathrm{N}$ use efficiency, and in some regions in the world, can lead to environment pollution, directly reflecting in the production costs and social costs of $\mathrm{N}^{16}$. Thereby, in the last years, the search for technologies that reduce nitrogen losses from urea has expanded. One of the ways to prevent $\mathrm{N}^{-\mathrm{NH}_{3}}$ losses consists of its mechanical incorporation to the soil ${ }^{17,3,9}$ or by the rainwater and irrigation ${ }^{2}$. However, the mechanical incorporation is not a recommended practice in the NT system due to the presence of straw and the fact that soil disruption should be avoided. Besides, mechanical incorporation is rarely adopted by Brazilian farmers, even in conventional systems. Thus, the use of conventional urea without incorporation is an option that is getting less common in agricultural regions of the world, in which there are initiatives and guidelines to mitigate ammonia emissions ${ }^{5}$.

Considering this challenge, the fertilizer industry and researchers around the world have turned their attention to the production of slow-release, controlled released or stabilized fertilizers in order to improve the $\mathrm{N}$ use efficiency in agriculture $\mathrm{e}^{3,14}$.

Stabilized fertilizers have additives that delay or inhibit some transformation process of $\mathrm{N}$ in the soil, such as the urease activity or the nitrification reaction. Several compounds such as NBPT (N-(n-Butyl) thiophosphoric triamide), NPPT (N-(n-Propyl) thiophosphoric triamide), metallic cations, boron, and organic $\mathrm{N}$ compounds have been studied with the aim of reducing urease activity in the soil and minimizing $\mathrm{N}$ losses to the atmosphere $2,18,19,5$.

Thus, it is increasingly important to adopt fertilizer technologies that are able to ensure greater $\mathrm{N}$ use efficiency towards 4R's stewardship. The use of slow-release, controlled and stabilized $\mathrm{N}$ fertilizers in order to mitigate $\mathrm{N}$ losses in corn production systems is very relevant in an agronomic and environmental scenarios.

Thus, the hypotheses of this study were: 1 ) the fertilizers: ammonium nitrate (AN), ammonium sulfate (AS), urea treated with NBPT $\left(\mathrm{U}_{\mathrm{NBPT}}\right)$, and urea treated with $\mathrm{Cu}$ and $\mathrm{B}\left(\mathrm{U}_{\mathrm{CuB}}\right)$ reduce $\mathrm{N}-\mathrm{NH}_{3}$ losses compared to

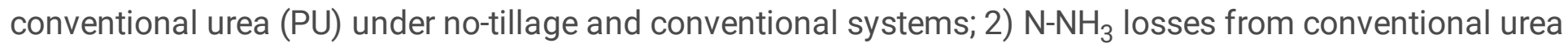
are higher in the no-tillage system, but urea technologies or the use of ammonium nitrate and ammonium sulfate can reduce such losses. To test these hypotheses, the present study was performed in two cropping systems (conventional and no-tillage) for two years under field conditions in southeastern Brazil, aiming to evaluate technologies for $\mathrm{N}$-fertilizers and their efficiency to mitigate $\mathrm{N}-\mathrm{NH}_{3}$ losses and improve corn nutrition and yield in the second crop season.

\section{Results}

\subsection{Ammonia Volatilization}


The daily losses of $\mathrm{N}-\mathrm{NH}_{3}$ in the $2017 / 2018$ crop season varied according to the $\mathrm{N}$ fertilizers applied in the no-tillage system (NT system) in relation to the conventional tillage (T system) (Fig. 1). In the T system, the

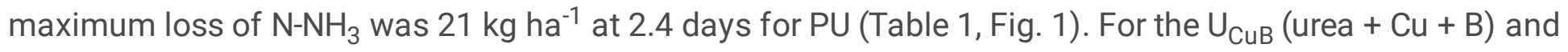
$\mathrm{U}_{\mathrm{NBPT}}$ (urea + NBPT $180 \mathrm{mg} \mathrm{kg}^{-1}$ ) treatments, the maximum losses were 6.8 and $1.6 \mathrm{~kg} \mathrm{~N}$ at 3.1 and 5.7 days after fertilization, respectively. The efficiency of these treatments to reduce $\mathrm{N}-\mathrm{NH}_{3}$ losses is evidenced when we observe the time in days for these treatments to reach 10,20 , and $50 \%$ of the maximum losses for PU (Prilled urea), which were 1.6, 2.4, and 4.2 days for $\mathrm{U}_{\mathrm{CuB}}$ and 2.2, 5.1 for $\mathrm{U}_{\mathrm{NBPT}}$. For $50 \%$ of the losses, $\mathrm{U}_{\mathrm{NBPT}}$ did not reach $50 \%$ of the maximum loss of PU (Table 1). In the NT system, the maximum loss for PU was $13.6 \mathrm{~kg} \mathrm{ha}^{-1}$ at 2.3 days after fertilization. The maximum loss values for the $U_{\text {CuB }}$ and $U_{\text {NBPT }}(180 \mathrm{mg}$ $\mathrm{kg}^{-1}$ ) treatments were 9.4 and $7.4 \mathrm{~kg} \mathrm{ha}^{-1}$ at 2.6 and 3.3 days after fertilization, respectively (Table 1, Fig. 1). In this case, the time in days for the occurrence of 10,20 , and $50 \%$ of the maximum losses for urea were 0.1 , 1.1 , and 2.6 days for $\mathrm{U}_{\mathrm{CuB}}$ and $0.9,2$, and 4 days for $\mathrm{U}_{\mathrm{NBPT}}$ (Table 1). The AS (Ammonium sulfate) and AN (Ammonium nitrate) treatments had maximum losses between 2 and 7 days in both systems but with values lower than $0.5 \mathrm{~kg} \mathrm{~N} \mathrm{ha}^{-1}$.

The percentages of $\mathrm{N}^{-\mathrm{NH}_{3}}$ losses that occurred in the first seven days under the $\mathrm{T}$ system were 89,79 and $60 \%$ for the PU, $\mathrm{U}_{\mathrm{CuB}}$ and $\mathrm{U}_{\mathrm{NBPT}}$ treatments, respectively. As for $\mathrm{NT}$ system, these values were 82,80 and $74 \%$, for the $\mathrm{PU}, \mathrm{U}_{\mathrm{CuB}}$ and $\mathrm{U}_{\mathrm{NBPT}}$ treatments, respectively. Thus, more than $80 \%$ of the $\mathrm{N}^{-\mathrm{NH}_{3}}$ losses occurred during the first seven days after the application of PU.

In the 2018/2019 crop season, the $\mathrm{N}^{-\mathrm{NH}_{3}}$ losses were affected by the $\mathrm{N}$ sources applied and cropping

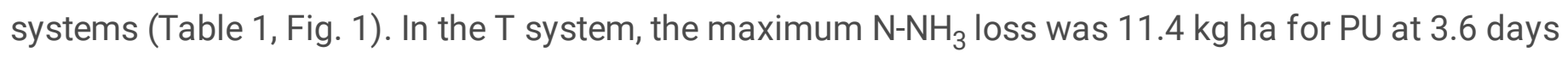
(Table 1, Fig. 1). The $U_{\text {CuB }}$ and $U_{\text {NBPT }}$ treatments had losses of 10.6 and $8 \mathrm{~kg} \mathrm{~N} \mathrm{ha}^{-1}$ at 4.3 and 8.6 days after application, respectively. The time needed to reach 10,20 , and $50 \%$ of the maximum losses for PU were 2.3 , 3 , and 4 days for $\mathrm{U}_{\mathrm{CuB}}$ and $7,7.6$, and 9 days for $\mathrm{U}_{\mathrm{NBPT}}$. As for the losses in the $\mathrm{NT}$ system, the day of maximum PU loss was similar to the $T$ system $\left(9.6 \mathrm{~kg} \mathrm{ha}^{-1}\right.$ at 3.9 days). In the $\mathrm{U}_{\mathrm{CuB}}$ and $\mathrm{U}_{\mathrm{NBPT}}$ treatments, the maximum losses occurred at 5 and 9 days, with values of 6.6 and $6.3 \mathrm{~kg}$ of N ha-1, respectively. However, the time needed to reach 10,20 , and $50 \%$ of the maximum loss for PU was higher than the T system, with values of $1.7,2.7$, and 5 days for $\mathrm{U}_{\mathrm{CUB}}$ and $7.5,8.3$, and 11 days for $\mathrm{U}_{\mathrm{NBPT}}$ (Table 1 ). As for the 2017/2018 crop season, the AS and AN treatments had maximum loss between 1 and 14 days, but with values below $0.2 \mathrm{~kg}$ of $\mathrm{N} \mathrm{ha}^{-1}$ (Table 1, Fig. 1).

In the T system, PU had the higher percentage of volatilized $\mathrm{N}^{-\mathrm{NH}_{3}}$ in the first seven days ( $92 \%$ ), followed by $\mathrm{U}_{\mathrm{CuB}}$ and $\mathrm{U}_{\mathrm{NBPT}}$, with $67 \%$ and $8 \%$, respectively. As for the NT system, the accumulated losses in the first seven days were $88 \%(\mathrm{PU}), 70 \%\left(\mathrm{U}_{\mathrm{CuB}}\right)$ and $10 \%\left(\mathrm{U}_{\mathrm{NBPT}}\right)$. Similarly to the $2017 / 2018$ crop season, the losses for PU reached approximately $90 \%$ until the $7^{\text {th }}$ day relatively to the 29 days of collection.

The accumulated $\mathrm{N}-\mathrm{NH}_{3}$ losses were affected $(\mathrm{p}<0.05)$ by the interaction between the applied fertilizers and the cropping systems in the $2017 / 2018$ crop season. The mean accumulated losses of $\mathrm{N}^{-\mathrm{NH}_{3}}$ by 
volatilization under NT system $\left(21.6 \mathrm{~kg} \mathrm{~N} \mathrm{ha}^{-1}\right)$ were $49 \%$ greater relatively to the T system $\left(14.5 \mathrm{~kg} \mathrm{~N} \mathrm{ha}^{-1}\right)$ (Fig. 2).

In the $2017 / 2018$ season, the accumulated $\mathrm{N}^{-\mathrm{NH}_{3}}$ losses presented the following decreasing order for the NT system: PU $\left(49 \mathrm{~kg} \mathrm{ha}^{-1}\right)>\mathrm{U}_{\mathrm{CuB}}\left(47 \mathrm{~kg} \mathrm{ha}^{-1}\right)>\mathrm{U}_{\mathrm{NBPT}}\left(41 \mathrm{~kg} \mathrm{ha}^{-1}\right)>\mathrm{AS}\left(5.5 \mathrm{~kg} \mathrm{ha}^{-1}\right)=\mathrm{NA}\left(2 \mathrm{~kg} \mathrm{ha}^{-1}\right)$. In the T system, the accumulated losses decreased as follows: $\mathrm{PU}\left(43 \mathrm{~kg} \mathrm{ha}^{-1}\right)>\mathrm{U}_{\mathrm{CuB}}\left(29 \mathrm{~kg} \mathrm{ha}^{-1}\right)>\mathrm{U}_{\mathrm{NBPT}}(19 \mathrm{~kg}$ $\left.\mathrm{ha}^{-1}\right)>$ AS $\left(3.6 \mathrm{~kg} \mathrm{ha}^{-1}\right)=\mathrm{AN}\left(2 \mathrm{~kg} \mathrm{ha}^{-1}\right)$ (Table 2, Fig. 2). Observing the influence of the cropping systems on the accumulated $\mathrm{N}-\mathrm{NH}_{3}$ losses, only the $\mathrm{U}_{\mathrm{NBPT}}, \mathrm{U}_{\mathrm{CuB}}$, and UP treatments showed losses 53,37 , and $11 \%$ higher in the NT system than the T system.

In the $2018 / 2019$ season, accumulated $\mathrm{N}^{-\mathrm{NH}_{3}}$ losses were also affected $(\mathrm{p}<0.05)$ by the interaction between the applied fertilizers and the cropping systems. The mean accumulated $\mathrm{N}^{-\mathrm{NH}_{3}}$ losses under $\mathrm{NT}$ were $26.2 \%$ greater than the losses observed under T system (Fig. 2).

The accumulated $\mathrm{N}^{-\mathrm{NH}_{3}}$ losses for $\mathrm{NT}$ decreased as follows: $\mathrm{PU}\left(47 \mathrm{~kg} \mathrm{ha}^{-1}\right)=\mathrm{U}_{\mathrm{CuB}}\left(45 \mathrm{~kg} \mathrm{ha}^{-1}\right)>\mathrm{U}_{\mathrm{NBPT}}(28$ $\left.\left.\mathrm{kg} \mathrm{ha}^{-1}\right)>\mathrm{AN}\left(1.7 \mathrm{~kg} \mathrm{ha}^{-1}\right)-1\right)=$ AS $\left(1.5 \mathrm{~kg} \mathrm{ha}^{-1}\right)$. As for the T system, the accumulated $\mathrm{N}^{-\mathrm{NH}_{3}}$ losses decreased in the following sequence: $U_{\text {CuB }}\left(38 \mathrm{~kg} \mathrm{ha}^{-1}\right)>P U\left(30 \mathrm{~kg} \mathrm{ha}^{-1}\right)=U_{\text {NBPT }}\left(27 \mathrm{~kg} \mathrm{ha}^{-1}\right)>\mathrm{AS}(2 \mathrm{~kg} \mathrm{ha}$ $\left.{ }^{1}\right)=\mathrm{AN}\left(1.4 \mathrm{~kg} \mathrm{ha}^{-1}\right)$ (Table 2, Fig. 2). The accumulated $\mathrm{N}^{-\mathrm{NH}_{3}}$ losses were 15 and $36 \%$ higher in the NT system than in the $T$ system for the $\mathrm{U}_{\mathrm{CuB}}$ and PU treatments, whereas the other treatments did not differ. In both crop seasons and cropping systems, the accumulated losses of $\mathrm{N}-\mathrm{NH}_{3}$ in the AS and NA treatments were equal to the control treatment, without $\mathrm{N}$ application.

For a better understanding of the studied technologies within cropping systems, the losses from both crop seasons were added, and using these values, we calculated the percentage increase of the losses under NT system relatively to $T$ system (Table 2). When interpreting these results, we notice that the percentage of increase in the losses NT system > T system varied between 5 and $38 \%$ (Table 2).

\subsection{Effects of Fertilizers and Soil Nitrogen Stocks on Nutrient Accumulation and Corn Yield}

For the $2017 / 2018$ crop season, the $\mathrm{N}$ extraction by the grains (Fig. S1), corn straw (straw), and total extraction (grains + straw) were not influenced $(p \geq 0.05)$ by the interaction between $N$ fertilizer and tillage system. When evaluating these factors separately, there was effect $(p \leq 0.05)$ on the $\mathrm{N}$ extraction by the corn straw (straw) and total extraction (grains + straw) as a function of the $\mathrm{N}$ sources. It was observed a difference in the $\mathrm{N}$ extraction values only between the $\mathrm{N}$ sources applied in relation to the control, without $\mathrm{N}$ application (Fig. S1).

The extraction of $N$ by corn grains in the $2018 / 2019$ crop season was not affected ( $p \geq 0.05$ ) by the interaction between sources and cropping systems, nor by the isolated effect of these factors. The mean $\mathrm{N}$ extraction by the grains was $182 \mathrm{~kg}$ of $\mathrm{N} \mathrm{ha}^{-1}$ (Fig. S2 A). The $\mathrm{N}$ extraction by straw was not influenced by 
the interaction between fertilizers sources and cropping systems $(p \geq 0.05)$, only by the effect of fertilizer sources (Fig. S2 A). The lowest $\mathrm{N}$ extraction by the straw occurred in the control treatment (44 kg ha-1) (Fig. $\mathrm{S} 2 \mathrm{~A}$ ). The total $\mathrm{N}$ extraction (grains + straw) was influenced by the interaction between tillage system and $\mathrm{N}$ source $(\mathrm{p} \leq 0.05)$. The lowest total $\mathrm{N}$ extraction was observed in the treatments control $\left(199 \mathrm{~kg} \mathrm{ha}^{-1}\right)$ and $\mathrm{U}_{\text {CuB }}\left(224 \mathrm{~kg} \mathrm{ha}^{-1}\right)$ under NT system; the other treatments did not differ from each other (Fig. S2 B). Regarding the tillage systems, there was a difference only for $U_{\mathrm{CuB}}$, with greater $\mathrm{N}$ extraction $\left(318 \mathrm{~kg} \mathrm{ha}^{-}\right.$ ${ }^{1}$ ) under NT system (Fig. S2 B).

Corn grain yield and production of straw were not affected by the $\mathrm{N}$ sources applied and the tillage system ( $T$ and NT) in both crop seasons ( $p \geq 0.05)$ (Fig. S3).

In the $2017 / 2018$ crop season, the average grain yield of the $\mathrm{N}$ sources varied between 9,532 and 10,982 $\mathrm{kg}$ $\mathrm{ha}^{-1}$ under T system, and between 8,914 and $10,895 \mathrm{~kg} \mathrm{ha}^{-1}$ under NT system. The straw production varied between 6,431 e 7,513 $\mathrm{kg} \mathrm{ha}^{-1}$ under T system, and between 6,124 and 6,988 $\mathrm{kg} \mathrm{ha}^{-1}$ under NT system (Fig. S3 B).

In the 2018/2019 crop season, the averages observed in the studied $N$ sources ranged between 11,622 and $15,795 \mathrm{~kg} \mathrm{ha}^{-1}$ under T system, and between 11,533 and $15,799 \mathrm{~kg} \mathrm{ha}^{-1}$ under NT system (Fig. S3 C). The average straw production in the 2018/2019 crop season ranged between 8,634 and 11,600 kg ha-1 under T system, and between 7,848 and $10,948 \mathrm{~kg} \mathrm{ha}^{-1}$ under NT system (Fig. S3 D).

\section{Discussion}

Observing the behavior of the evaluated $\mathrm{N}$ fertilizers regarding the daily losses, we noted that the highest values in both crop seasons occurred with the application of PU, approximately 2.5 days after the application in both crop seasons and cropping systems (Table 1, Fig. 1). That is because when urea is applied to the soil, without any additive or technology that reduces its solubility or the hydrolysis rate, ammonia is rapidly created in the solution and catalyzed by urease into $\mathrm{NH}_{3}$ and $\mathrm{CO}_{2}{ }^{14,10}$. If not incorporated, this ammonia becomes susceptible to losses by volatilization.

In our study, rainfall up to the second day after fertilization was 85 and $28 \mathrm{~mm}$ in the first and second year, respectively (Fig. S6). However, it is complicated to accurately inform the amount and intensity of rainfall needed to incorporate urea into the soil since the values obtained were insufficient. Similar to what was observed in the application of PU, several studies also demonstrate that the maximum daily loss of $\mathrm{N}-\mathrm{NH}_{3}$ occurs in the first days following the application of the fertilizers $20,21,11$. Thus, we can argue that these losses will occur in the first days for urea without any treatment or technology, as long as the moisture conditions allow the hydrolysis process. The moisture conditions do not rely only on rainfall, since a value of relative air humidity above $74.3 \%$ (critical humidity of urea at $30^{\circ} \mathrm{C}$ ) can already start the hydrolysis process4. In our study, in the first crop season, the mean temperature was higher than $30^{\circ} \mathrm{C}$, and the relative air humidity was higher than the critical humidity of urea in both crop seasons (Fig. S6). Such increased air humidity can promote increased $\mathrm{N}-\mathrm{NH}_{3}$ losses, even without rainfall. 
The delay in the day of maximum loss observed in both systems for the stabilized fertilizers $\left(\mathrm{U}_{\mathrm{CuB}}\right.$ and $U_{\text {NBPT }}$ ) compared to $\mathrm{PU}$ is due to the inhibition mechanism of each technology. For $U_{\mathrm{NBPT}}$, this reduction in urease activity is due to the ability of NBPT to be oxidized into its analog compound NBPTO, which can inhibit the urease activity by forming stable complexes with the enzyme ${ }^{22}$. As for $\mathrm{U}_{\mathrm{CuB}}$, urease activity is inhibited due to the binding of Cu to the sulfhydryl group. Such binding blocks the active site of the enzyme, and the urea molecule cannot bind to the sulfhydryl group. Thus, the urea hydrolysis process cannot occur $^{23}$. The effect of $\mathrm{B}$ on urease inhibition diverges among different authors, but according to Santos et al. ${ }^{11}$, the study by Benini et al. ${ }^{24}$ provides a better explanation. These authors attribute the efficiency of $\mathrm{B}$ to its competitive inhibition when binding between the Ni ions of the enzyme, where the urea molecule would bind, which prevents the hydrolysis process from occurring.

The delayed urea hydrolysis when using these two technologies may favor the incorporation of fertilizers into the soil after subsequent precipitation events, which may reduce $\mathrm{N}-\mathrm{NH}_{3}$ losses. This effect occurred for both sources in the $2017 / 2018$ crop season. After the $5^{\text {th }}$ day, which had a 42-mm rainfall (Fig. S6), fertilizers were probably incorporated into the soil. Then, the daily $\mathrm{N}^{-\mathrm{NH}_{3}}$ losses decreased from that point (Fig. 1).

The inhibition of urease by NBPT, indirectly observed by the $\mathrm{N}^{-\mathrm{NH}_{3}}$ losses, occurs in varying intensities between the NT system and T system (Fig. 1). In our study, such behavior is evidenced by increasing the NBPT concentration in urea from $180 \mathrm{mg} \mathrm{kg}^{-1}$ to $1200 \mathrm{mg} \mathrm{kg}^{-1}(2017 / 2018)$ in the second year of the experiment. We noticed that the day of the maximum loss for the $U_{\text {NBPT }}$ treatment $\left(1200 \mathrm{mg} \mathrm{kg}^{-}\right.$ ${ }^{1}$ ) under $\mathrm{T}$ system was delayed, occurring at the $8.5^{\text {th }}$ day after application. This represents a delay of $67 \%$ relatively to the previous crop season (Table 1, Fig. 1). When observing the day when the maximum loss occurred under NT system, we noticed that there was no differences between the tillage systems (Table 1), thus we can deduce that this concentration was efficient for both cropping systems.

However, we cannot interpret this concentration $\left(1200 \mathrm{mg} \mathrm{kg}^{-1}\right)$ as adequate for the treatment of urea to be used in both systems, and that is because, theoretically in the T system this concentration can be lower, which also reflects the efficient use of the inhibitor. These results show that the amount of NBPT used in the treatment of urea may need an adjustment as a function of the soil and crops conditions, that is, it is needed to generate more precise information about the relationship between the NBPT concentration and the values of urease activity.

Despite the positive results reported on the use of these metals, in the 2017/2018 crop season we observed that the maximum loss of $\mathrm{U}_{\mathrm{CuB}}$ occurred in a time frame (days) similar to PU under $\mathrm{T}$ system (Table 1). The lower efficiency of $\mathrm{U}_{\mathrm{CuB}}$ can be explained by the low concentration of micronutrients ( $\mathrm{Cu}$ and $\mathrm{B}$ ) in the fertilizer. Furthermore, it should be emphasized that the amount of metallic cations and compounds containing mostly $B$ added to urea aiming the inhibition of urease should be carefully evaluated. In this study $0.3 \%$ of $\mathrm{Cu}$ (copper sulfate) and $0.3 \%$ of $\mathrm{B}$ (boric acid) were added to urea, which, considering the dose of $150 \mathrm{~kg} \mathrm{ha}^{-1}$, correspond to $450 \mathrm{~g}$ of $\mathrm{Cu}$ and $\mathrm{B}$ in the region of the dissolution of urea. 
The fact that the other sources used in this study (AS, AN) did not promote significant daily losses is due to the $\mathrm{N}$ form present in the AS and AN fertilizers, and also due to their acidic reaction, which creates a less favorable environment to the $\mathrm{N}-\mathrm{NH}_{3}$ losses by volatilization, as previously reported in several studies ${ }^{25,26,4}$.

The accumulated $\mathrm{N}-\mathrm{NH}_{3}$ losses were higher under NT system than under T system in both crop seasons (Fig. 2). This occurred as a result of the greater presence of crop residues (straw) in this system, which favors the rapid hydrolysis of the fertilizer due to the increased urease activity ${ }^{27,28}$. Moreover, the crop residues present in the NT system reduce the diffusion of urea in the soil by reducing the contact urea/soil and preserving soil moisture ${ }^{15,2,7}$.

Our findings demonstrate alternatives to reduce urease activity and ${\mathrm{N}-\mathrm{NH}_{3}}_{3}$ losses in NT systems, which would be the use of technologies that enhance urea use efficiency. Thus, $\mathrm{U}_{\mathrm{NBPT}}$ stands out as the best technology as it reduced, on average, $28 \%$ of losses relatively to PU in NT system for both crop seasons (Table 2). Another technology that may be used is the coating with metallic ions and compounds containing B. However, $\mathrm{Cu}$ and $\mathrm{B}$ concentrations deserve further investigation since, in our study, the reduction of $\mathrm{N}^{-\mathrm{NH}_{3}}$ losses was only $3 \%$ on average for both crop seasons (Table 2).

Owing to their acidic reaction, the AS and AN sources presented the lowest accumulated losses. The accumulated losses observed for these sources (lower than 0,5\%) are already reported in several studies conducted in soils cultivated under this $\mathrm{pH}$ range ${ }^{29,2,4}$. These values of $\mathrm{N}-\mathrm{NH}_{3}$ losses quantified for $\mathrm{AS}$ and AN are not from these fertilizers, since they are equal to the values observed in the soil without $\mathrm{N}$ application. This shows that these losses occur naturally even in the control treatment without $\mathrm{N}$ fertilization.

The reductions in $\mathrm{N}-\mathrm{NH}_{3}$ losses by volatilization were not followed by expressive increases in $\mathrm{N}$ extraction by corn. In both crop seasons, the low extraction by corn straw in the control treatment (Fig. S1, $\mathrm{S} 2$ ) is due to the absence of $\mathrm{N}$ fertilization.

Our findings regarding the $\mathrm{N}$ extraction by the corn are already reported in other studies conducted with similar objectives. Cancellier et al. ${ }^{2}$ did not observe differences in $\mathrm{N}$ extraction by the grains and corn shoot between conventional urea, urea + NBPT and urea $+\mathrm{Cu}+\mathrm{B}$. The authors found that the $\mathrm{N}$ extraction was $61 \mathrm{~kg} \mathrm{ha}^{-1}$ in the control treatment, without $\mathrm{N}$ application, and the average between treatments was 82 $\mathrm{kg} \mathrm{ha}^{-1}$.

The grain yield in both crop seasons (Fig. S3) was twice the average Brazilian yield $\left(5029 \mathrm{~kg} \mathrm{ha}^{-1}\right)^{30}$. The absence of responses regarding treatments and cropping systems is related to the high $\mathrm{N}$ supply by the soil (Tables 5 and S1). This is due to the increased $\mathrm{N}$ stock in the soil (192 kg ha-1 on average) and also to the potential of $\mathrm{N}$ mineralization in the soil (162 kg ha-1 year $^{-1}$ on average), which has been under NT system for at least 15 years (Table S1).

Other results on grain yield, $\mathrm{N}$ extraction by the grains and straw show that there is reduction of ammonia losses with the use of inhibitors and other technologies for fertilizers, but these losses were not followed by 
increased $\mathrm{N}$ extraction by the grains, straw and yield ${ }^{31,14,32}$, although they did not estimate the potential supply of $\mathrm{N}$ by the soil organic matter.

In order to explain this absence of response to the $\mathrm{N}$ fertilization, interpreting the data on table $\mathrm{S} 2$, we can observe that this soil had the potential supply of approximately $280 \mathrm{~kg} \mathrm{~N} \mathrm{ha}^{-1}$ in the $2017 / 2018 \mathrm{crop}$ season and proximately $400 \mathrm{~kg} \mathrm{~N} \mathrm{ha}^{-1}$ in 2018/2019; thus, the application of $150 \mathrm{~kg} \mathrm{~N} \mathrm{ha}^{-1}$ will hardly present a response in yield. These results do not seem interesting if we only take the economic aspects in consideration, however, the maintenance of $\mathrm{N}$ in the soil organic matter is as important as the increase in crop yield. Besides the fact that $\mathrm{N}$ is stored in the soil for the future crop seasons, this maintenance of $\mathrm{N}$ in the soil organic matter mitigates the emission of greenhouse gases to the atmosphere.

\section{Methods}

\subsection{Preparation and characterization of the used fertilizers}

In the $2017 / 2018$ crop, the $\mathrm{N}$ sources were: Urea treated with NBPT, with $46 \% \mathrm{~N}$ and $180 \mathrm{mg} \mathrm{NBPT} \mathrm{kg}^{-}$ $1\left(\mathrm{U}_{\mathrm{NBPT}}\right)$; 2$)$ Prilled Urea, with $46 \% \mathrm{~N}(\mathrm{PU})$; 3$)$ Urea treated with $\mathrm{Cu}$ and $\mathrm{B}$, with $43 \% \mathrm{~N}, 0.3 \% \mathrm{Cu}$, and $0.3 \% \mathrm{~B}$ $\left(\mathrm{U}_{\mathrm{CuB}}\right)$; 4) Ammonium nitrate, with $33 \% \mathrm{~N}(\mathrm{AN})$, and 5) Ammonium sulfate, with $19 \% \mathrm{~N}$ and $22 \% \mathrm{~S}(\mathrm{AS})$. All fertilizers were purchased from a fertilizer store. As for the 2018/2019 crop season, the $U_{\text {NBPT }}$ was treated in the laboratory since the NBPT concentration in the fertilizer obtained in the 2017/2018 season was lower than that described in the commercial fertilizer $\left(530 \mathrm{mg} \mathrm{kg}^{-1}\right)$. The other fertilizers were obtained from a fertilizer store.

The treatment of urea with NBPT used in the 2018/2019 crop season was performed at the Laboratory of Technologies for Fertilizers at the Federal University of Lavras. For that, a solution including diethanolamine (CAS number 111-42-2) (70 \%) and NBPT (30\%) was prepared. From this solution, $8.6 \mathrm{~g}$ were taken and homogenized with $2 \mathrm{~kg}$ of granular urea in a bench top mixer. Afterwards, the NBPT concentration was determined by high-performance liquid chromatography (HPLC), model HP1100 Agilent with diode-array detection (DAD) ${ }^{33}$, which was $1,200 \mathrm{mg} \mathrm{kg}^{-1}$.

\subsection{Site Description and Management Practices}

Two experiments with corn (Zea mays), hybrid 2B-512PW of the Dowscience ${ }^{\circledR}$ company were performed during the second crop season of 2017/2018 and 2018/2019, after the cultivation of soybean (Glycine max), in Medeiros and Bambuí, Minas Gerais state, Brazil $\left(20^{\circ} 07^{\prime} 00^{\prime \prime} \mathrm{S}, 46^{\circ} 09^{\prime} 55^{\prime \prime}\right.$ W and $20^{\circ} 06^{\prime} 47^{\prime \prime}$ S, $46^{\circ} 10^{\prime} 00^{\prime \prime} \mathrm{W}$, respectively (Fig. 3). The experiments were installed in a slope within a hilly region, in a soil classified Acrudox ${ }^{34}$. In both cultivation years, all experiments were performed in accordance with relevant guidelines and regulations. As these are experiments carried out in partnership between the research institutions involved and the Farm where they were carried out, the authors declare that all necessary permissions for the collection of plants have been obtained. 
The information regarding the main characteristics of the sites and crop seasons are summarized on table 3.

\subsection{Cropping Systems and Field Management}

The rationale of this study emerged after reading some papers previously published in the scientific literature. Table 4 lists the main results on the subject found in the scientific literature.

Since the aim of this study is the comparison between the $\mathrm{N}$ fertilizers and their technologies, and also the influence of the tillage systems on the $\mathrm{N}^{-\mathrm{NH}_{3}}$ losses by volatilization, we decided to simulate the conventional tillage (T system) within a no-till system (NT system) area that had approximately 15 years of implantation. To simulate the T system in the NT system area, the straw was manually removed from the plots designed to represent the T system, and the soil was plowed up to $20 \mathrm{~cm}$ depth in the 2016/2017 and 2017/2018 summer crop seasons (Fig. S4). Thus, corn sowing (second crop season) was performed after soybean cultivation in the summer for both years. Before the sowing, soil samples were collected for chemical and physical characterization. Six composite samples were collected, obtained from a homogenous mixture of ten simple soil samples collected at the $0-0.05,0.05-0.10$ and $0.10-0.20 \mathrm{~m}$ soil depths. The clay, silt, and sand content values were 40, 31, 29\% and 44; 36; 20\% for the 2017/2018 and $2018 / 2019$ crop seasons, respectively, and the results of the chemical analysis are presented on tables 5 and S1.

Furthermore, soil samples were collected to determine bulk density, and stocks of total N (Ntotal), total C (Ctotal), and mineral N (Nmineral). Soil bulk density was determined by the core method ${ }^{35}$. Total $\mathrm{N}$ was determined by the Kjeldhal method ${ }^{36}$. The mineral $\mathrm{N}$ was determined by extraction with $1 \mathrm{~mol} \mathrm{~L}^{-1} \mathrm{KCl}$ and magnesium oxides and devarda's alloy ${ }^{37}$. The stocks of total $\mathrm{N}$, mineral $\mathrm{N}$, and total carbon from each soil depth were calculated according as described in Santos et al. ${ }^{11}$ (Table 5).

\subsection{Estimate of $\mathbf{N}$ Mineralization in the Soil}

We were interested in monitoring the behavior of $\mathrm{N}$ and their Technologies when applied in both tillage systems. For that, we decided to estimate the mineralization of $\mathrm{N}$ in both tillage systems. The objective was to perform a complete characterization of the studied areas and also explain some behaviors of the tillage systems in relation to the evaluated agronomic parameters. For this, the estimation of $\mathrm{N}$ mineralization was performed as proposed by Brady and Weil ${ }^{38}$, with adaptations described in Santos et al. $^{11}$.

The data used on this estimate can be found on table 5 , and since both experiments were conducted in soils with clayey texture under tropical conditions, we adopted the value of $3 \%$ of annual $\mathrm{N}$ mineralization, as proposed by Brady and Weil ${ }^{38}$. The results of the estimate of $\mathrm{N}$ mineralization in the studied soils are presented on table S2.

\subsection{Treatments and Experimental Design}


The experiments consisted of fourteen (12) treatments setup in a 6 × 2 factorial scheme ( $\mathrm{N}$ fertilizers and their technologies applied in the soil as top dressing fertilization: 1) prilled urea (PU), 2) urea treated with NBPT (N-(n-butyl) thiophosphoric triamide), 3) urea + $\left.\mathrm{Cu}+\mathrm{B}\left(\mathrm{U}_{\mathrm{CuB}}\right), 4\right)$ ammonium nitrate $\left.(\mathrm{AN}), 5\right)$ ammonium sulfate (AS), and 6) without $\mathrm{N}$ application - control; and tillage systems management for corn cultivation: conventional tillage (T system) and no-till (NT system) (Fig. S5).

The sowing of corn in the $2017 / 2018$ crop season was performed along with the application of $18 \mathrm{~kg} \mathrm{~N} \mathrm{ha}^{-1}$ and $11.4 \mathrm{~kg} \mathrm{P}_{2} \mathrm{O}_{5} \mathrm{ha}^{-1}$ (formula 27-17-00). In the 2018/2019 crop season, the sowing was performed along with $18 \mathrm{~kg} \mathrm{~N} \mathrm{ha}^{-1}$ and $32 \mathrm{~kg} \mathrm{P}_{2} \mathrm{O}_{5} \mathrm{ha}^{-1}$ (Bulk blend of fertilizers 14-25-00).

The spacing between rows was $0.75 \mathrm{~m}$, totaling 55,000 plants per hectare. Each experimental plot consisted of six sowing rows with $5 \mathrm{~m}$ length each. $150 \mathrm{~kg} \mathrm{~N} \mathrm{ha}^{-1}$ were applied via top dressing fertilization. Fertilizers were applied in the sowing lines at a distance of approximately $10 \mathrm{~cm}$ from the plant collar. The three central meters and three central lines of each plot $\left(6.75 \mathrm{~m}^{2}\right)$ were considered the useful plot.

\subsubsection{Ammonia Volatilization}

To quantify the $\mathrm{N}^{-\mathrm{NH}_{3}}$ losses, PVC (Polyvinyl chloride) collectors were used as described by Nönmik ${ }^{39}$, and adapted by Lara-Cabezas et al. ${ }^{40}$. As a support of the collectors, three bases of PVC tubes were installed in each experimental plot at a distance of $10 \mathrm{~cm}$ from the corn sowing row. The bases had $12 \times 20 \times 5 \mathrm{~cm}$ (diameter, height, and depth in the soil).

After the application of the treatments in the bases, $\mathrm{N}-\mathrm{NH}_{3}$ collectors with dimensions $50 \times 12 \mathrm{~cm}$ (height and diameter, respectively) were installed. Two sponges $\left(0.02 \mathrm{~g} \mathrm{~cm}^{-3}\right.$ density $)$ soaked with phosphoric acid solution $\left(60 \mathrm{ml} \mathrm{L}^{-1}\right)$ and glycerin $\left(50 \mathrm{ml} \mathrm{L}^{-1}\right)$ were placed inside each collector. The sponge located in the upper part of the collector meant to prevent the contamination of the lower sponge with gases from the atmosphere, whereas the sponge at the lower part was used to absorb the ammonia volatilized. In order to reduce the spatial variability of the $\mathrm{N}_{-} \mathrm{NH}_{3}$ losses, and to simulate the field conditions, such as temperature and precipitation, the collectors were alternated between the three bases. Thus, after each collection of sponges, the collector was changed from its base.

The $\mathrm{N}-\mathrm{NH}_{3}$ collections were carried 1, 2, 3, 4, 5, 7, 10, 14, 19, 23 and 29 days after the application of the treatments in the top dressing fertilization of corn. The solution in sponges collected in the field was extracted and analyzed as described in Santos et al. ${ }^{11}$.

After calculating the $\mathrm{N}$ levels in the samples, the obtained value (corresponding to the area occupied by the base with the chambers installed in the field) was extrapolated to the percentage of $\mathrm{N}_{-} \mathrm{NH}_{3}$ loss per hectare. To calculate the accumulated losses during the 29 days, losses from the $1^{\text {st }}$ and the $2^{\text {nd }}$ day were added; the sum of these added to the $3^{\text {rd }}$ day and so on. During the period of evaluation of $\mathrm{N}^{-\mathrm{NH}_{3}}$ losses by volatilization, the climate data were collected by the automatic weather station from the Ministry of Agriculture (MAPA), located in Bambuí, Minas Gerais State, Brazil. 


\subsubsection{Weather Conditions}

Data on rainfall, relative air humidity, and maximum and minimum temperature were recorded by the meteorological station of the farm. Data were collected throughout the entire period of evaluation of $\mathrm{N}-\mathrm{NH}_{3}$ losses by volatilization. Rainfall, maximum and minimum temperature values, and relative air humidity after 29 days of the application of top dressing $\mathrm{N}$ fertilization in both experiments in Medeiros e Bambuí in the 2017/2018 and 2018/2019 crop season are presented on Figure S6.

In the $2017 / 2018$ crop season, precipitations of $45,18,10$ e $42.5 \mathrm{~mm}$ occurred in the first seven days after the application of the $\mathrm{N}$ fertilizers, totaling $115.5 \mathrm{~mm}$ of precipitation; the average temperature was $23.5^{\circ} \mathrm{C}$. As for the 2018/2019 crop season, precipitations of 7.5, 24, 11, 41 e $5 \mathrm{~mm}$ occurred in the first seven days after the application of the treatments, totaling $80.5 \mathrm{~mm}$; the average temperature was $23^{\circ} \mathrm{C}$. During the entire growth cycle of the corn, the precipitation was $435 \mathrm{~mm}$ and 372 in the 2017/2018 and 2018/2019 crop seasons, respectively.

\subsubsection{Nitrogen Accumulation and Corn Yield}

When the corn grains reached the physiological maturity, the corn cobs were harvested and separated from the culm and leaves (which correspond to the straw). The grains were removed from the cobs using a thresher and afterwards, the grain moisture was quantified using a Gehaka ${ }^{\circledR}$ equipment $\mathrm{G} 600$ for subsequent correction of moisture to $13 \%$. Then, this value was extrapolated to represent the grain yield in $\mathrm{kg} \mathrm{ha}^{-1}$. From this sample of grains, a subsample was taken and oven dried at $65^{\circ} \mathrm{C}$ for subsequent analysis of $\mathrm{N}$ content in the grains.

To estimate the straw production, the samples were weighed, grinded in a forage harvester, and had subsamples taken for determination of moisture content. Afterwards, the results were extrapolated to production of straw per hectare, and the values were given in $\mathrm{kg} \mathrm{ha}^{-1}$. Similar to the grains, subsamples of straw were dried and grinded in a Willey mill for analysis of $\mathrm{N}$ content by the Kjedahl method ${ }^{36}$ and following the methodology described by Tedesco et al. ${ }^{37}$.

\subsection{Statistical Analysis}

The treatments were submitted to a non-linear regression analysis using a logistic model to evaluate the losses of ammonia by volatilization, equation (1):

$$
Y i=\left[\frac{\alpha}{1+e^{k}(b-\text { daai })}\right]+E i
$$

\section{Equation 1}

in which, $Y i$ is the i-th observation of the accumulated loss of $\mathrm{N}^{-\mathrm{NH}_{3}}$ in $\%$, being $i=1,2, \ldots, n ; \mathrm{daa}_{i}$ is the i-th day after the application of the treatment; $a$ is the asymptotic value that can be interpreted as the maximum 
amount of accumulated loss of $\mathrm{N}-\mathrm{NH}_{3} ; b$ is the abscissa of the inflection point and indicates the day when the maximum loss by volatilization occurs; $k$ is the value that represents the precocity index, and the higher its value, the lower the time needed to reach the maximum loss by volatilization (a); $E_{i}$ is the error associated to the $\mathrm{i}$-th observation, which is assumed to be independent and equally distributed according to a zero average standard and constant variance, $E \sim N\left(0, I \sigma^{2}\right)$.

This model has been largely applied to estimate plant growth, and recently, has been used to estimate the accumulated loss of $\mathrm{N}-\mathrm{NH}_{3} 40,19,42$.

To estimate the maximum daily loss (day when the highest loss of $\mathrm{N}-\mathrm{NH}_{3}$ occurred), that is, to determine the inflection point of the curve, it was used the following equation (2):

$$
\mathrm{PMD}=k \times(\alpha / 4)
$$

\section{Equation 2}

in which, $k$ is a relative index used to obtain to maximum daily loss (MDL), and $a$ is the asymptotic value that can be interpreted as the maximum amount of accumulated loss of $\mathrm{N}^{-\mathrm{NH}_{3}}$.

Analysis of variance was applied to test the influence of the fertilizers in the parameters: accumulated losses of ammonia by volatilization at the end of the evaluation days, grain yield, straw production, and $\mathrm{N}$ removal. The significance of the differences was evaluated in $\mathrm{P} \leq 0.05$, and after validating the statistic model, the mean values were grouped by the Scott-Knott algorithm using the $R$ software 3.3.1 $1^{43}$.

\section{Conclusions And Future Perspectives}

The technologies for urea reduce the $\mathrm{N}-\mathrm{NH}_{3}$ losses compared to $\mathrm{PU}$ in both studied systems, and the losses under NT system are higher than in T systems. Urea treated with NBPT $\left(1200 \mathrm{mg} \mathrm{kg}^{-1}\right)$ is an option of technology for the efficient $\mathrm{N}$ use in grain production systems under NT system, as it causes a 5-day delay in the day of maximum loss compared to urea treated with NBPT $\left(180 \mathrm{mg} \mathrm{kg}^{-1}\right)$. The use of ammonium nitrate and sulfate also represent adequate choices to reducing the $\mathrm{N}-\mathrm{NH}_{3}$ losses in grain production systems. In the present study, a reduction of $\mathrm{N}^{-\mathrm{NH}_{3}}$ losses does not directly reflect an increase in yield and $\mathrm{N}$ extraction by corn.

Based on the results observed in this study, we noticed that the NBPT concentration to be used in soils under NT system should be adjusted. Thus, studies that evaluate increasing NBPT concentrations in NT systems will be performed by our research group in order to better define the NBPT dose in formulations according to the varying conditions of grain production in tropical regions.

\section{Abbreviations}

NT system: no-tillage system, T system: conventional till system, $\mathrm{N}$ : nitrogen, $\mathrm{Cu}$ : cobre, $\mathrm{B}$ : boro, $\mathrm{N}^{-\mathrm{NH}_{3}}$ : nitrogen in the form of ammonia, no-N: control without nitrogen application; PU: Prilled urea, $\mathrm{U}_{\mathrm{NBP}}$ : urea + 
NBPT; $U_{\text {CuB }}$ : urea + Cu + B, AN: ammonium nitrate, AS: ammonium sulfate, CEC: cation exchange capacity, OM: organic matter, NOM: nitrogen in soil organic matter, OC: organic carbon, NBPT: N-(n-Butyl) thiophosphoric triamide, NPPT: N-(n-Propyl) thiophosphoric triamide, PVC: polyvinyl chloride

\section{Declarations}

Conflicts of interest: The authors declare that there is no conflict of interest.

Acknowledgements: The authors thank the Agency for the Improvement of Higher Education Personnel, the National Council for Scientific Development and Technology, and the Foundation for Research Support of Minas Gerais.

\section{References}

1. Bender, R. R., Haegele, J. W., Ruffo, M. L. \& Below, F. E. Nutrient uptake, partitioning, and remobilization in modern, transgenic insect-protected maize hybrids. Agron. J. 105, 161-170 (2013).

2. Cancellier, E. L. et al. Volatilização de amônia por ureia de eficiência aumentada no milho cultivado em solo de fertilidade construída. Ciênc. agrotec. 40, 133-144 (2016).

3. Pan, B., Lam, S. K., Mosier, A., Luo, Y. \& Chen, D. Ammonia volatilization from synthetic fertilizers and its mitigation strategies: A global synthesis. Agric. Ecosyst. Environ. 232, 283-289 (2016).

4. de Souza, T. L. et al. Emissões de amônia e de dióxido de carbono de fertilizantes nitrogenados convencionais, estabilizados e liberação controlada na cultura do milho. Ciênc. agrotec. 41, 494-510 (2017).

5. Byrne, M. P. et al. Urease and nitrification inhibitors-As mitigation tools for greenhouse gas emissions in sustainable dairy systems: A review. Sustainability (Switzerland) 12, (2020).

6. Klimczyk, M., Siczek, A. \& Schimmelpfennig, L. Improving the efficiency of urea-based fertilization leading to reduction in ammonia emission. Sci. Total Environ. 771, (2021).

7. Pinheiro, P. L. et al. Straw removal reduces the mulch physical barrier and ammonia volatilization after urea application in sugarcane. Atmos. Environ. 194, 179-187 (2018).

8. Sunderlage, B. \& Cook, R. L. Soil Property and Fertilizer Additive Effects on Ammonia Volatilization from Urea. Soil Sci. Soc. Am. J. 82, 253-259 (2018).

9. Pelster, D. E. et al. Effects of Initial Soil Moisture, Clod Size, and Clay Content on Ammonia Volatilization after Subsurface Band Application of Urea. J. Environ. Qual. 48, 549-558 (2019).

10. Santos, C. F. et al. Environmentally friendly urea produced from the association of N-(n-butyl) thiophosphoric triamide with biodegradable polymer coating obtained from a soybean processing byproduct. J. Clean. Prod. 276, (2020). 
11. Santos, C. F. et al. Dual Functional Coatings for Urea to Reduce Ammonia Volatilization and Improve Nutrients Use Efficiency in a Brazilian Corn Crop System. J. Soil Sci. Plant Nutr. 21, 1591-1609 (2021).

12. de Almeida, W. S. et al. Erosão hídrica em diferentes sistemas de cultivo e níveis de cobertura do solo. Pesqui. Agropecu. Bras. 51, 1110-1119 (2016).

13. Sales, R. P., Portugal, A. F., Alves Moreira, J. A., Kondo, M. K. \& Pegoraro, R. F. Qualidade física de um Latossolo sob plantio direto e preparo convencional no semiárido. Cienc. Agron. 47, 429-438 (2016).

14. Viero, F., Menegati, G. B., Carniel, E., da Silva, P. R. F. \& Bayer, C. Urease inhibitor and irrigation management to mitigate ammonia volatilization from urea in no-till corn. Rev. Bras. Ciênc. Solo 41, (2017).

15. Rojas, C. A. L., Bayer, C., Fontoura, S. M. V., Weber, M. A. \& Vieiro, F. Volatilização de amônia da ureia alterada por sistemas de preparo de solo e plantas de cobertura invernais no Centro-Sul do Paraná. Rev. Bras. Ciênc. Solo 36, (2012).

16. Keeler, B. L. et al. The social costs of nitrogen. Sci. Adv. 2, (2016).

17. Fontoura, S. M. V. \& Bayer, C. Adubação nitrogenada para alto rendimento de milho em plantio direto na região centro-sul do Paraná. Rev. Bras. Ciênc. Solo 33, (2009).

18. Naz, M. Y. \& Sulaiman, S. A. Slow release coating remedy for nitrogen loss from conventional urea: A review. J. Control. Release 225, 109-120 (2016).

19. Silva, A. G. B., Sequeira, C. H., Sermarini, R. A. \& Otto, R. Urease inhibitor NBPT on ammonia volatilization and crop productivity: A meta-analysis. Agron. J. 109, 1-13 (2017).

20. Sadeghpour, A. et al. Assessing Tillage Systems for Reducing Ammonia Volatilization from SpringApplied Slurry Manure. Commun. Soil Sci. Plant Anal. 46, 724-735 (2015).

21. Keshavarz Afshar, R., Lin, R., Mohammed, Y. A. \& Chen, C. Agronomic effects of urease and nitrification inhibitors on ammonia volatilization and nitrogen utilization in a dryland farming system: Field and laboratory investigation. J. Clean. Prod. 172, 4130-4139 (2018).

22. Sanz-Cobena, A., Misselbrook, T., Camp, V. \& Vallejo, A. Effect of water addition and the urease inhibitor NBPT on the abatement of ammonia emission from surface applied urea. Atmos. Environ. 45, 1517-1524 (2011).

23. Damodar Reddy, D., Sharma, K. L. \& Reddy, D. D. Effect of amending urea fertilizer with chemical additives on ammonia volatilization loss and nitrogen-use efficiency. Biol. Fertil. Soils 32,(2000).

24. Benini, S., Rypniewski, W. R., Wilson, K. S., Mangani, S. \& Ciurli, S. Molecular Details of Urease Inhibition by Boric Acid: Insights into the Catalytic Mechanism. J. Am. Chem. Soc. 126, 3714-3715 (2004).

25. Chagas, W. F. T. et al. Volatilização de amônia de blends com ureia estabilizada e de liberação controlada no cafeeiro. Ciênc. agrotec.40, 497-509 (2016). 
26. Dominghetti, A. W. et al. Perdas de nitrogênio por volatilização de fertilizantes nitrogenados em cultivo de café. Ciênc. agrotec.40, 173-183 (2016).

27. Longo, R. M. \& Melo, W. J. de. Atividade da urease em latossolos sob influência da cobertura vegetal e da época de amostragem. Rev. Bras. Ciênc. Solo 29, (2005).

28. Cantarella, H. Nitrogênio. in Fertilidade do Solo (eds. Novais, R. F. et al.) vol. 1 375-470 (2007).

29. Nascimento, C. A. C. do, Vitti, G. C., Faria, L. de A., Luz, P. H. C. \& Mendes, F. L. Ammonia volatilization from coated urea forms. Rev. Bras. Ciênc. Solo 37, (2013).

30. Conab. Acompanhamento da Safra Brasileira - Grãos. (2019).

31. Faria, L. de A., Nascimento, C. A. C. do, Vitti, G. C., Luz, P. H. de C. \& Guedes, E. M. S. Loss of ammonia from nitrogen fertilizers applied to maize and soybean straw. Rev. Bras. Ciênc. Solo 37, (2013).

32. Lucas, F. T., Borges, B. M. M. N. \& Coutinho, E. L. M. Nitrogen fertilizer management for maize production under tropical climate. Agron. J. 111, 2031-2037 (2019).

33. European Committee for Standardization. Fertilizers - Determination of N-(n Butyl) thiophosphoric acid triamide (NBPT) and N-(n-Propyl) thiophosphoric acid triamide (NPPT) - Method using high-performance liquid chromatography (HPLC). 1-7 (2015).

34. Soil Survey Staff. Keys to soil taxonomy. (2014).

35. Grossman, R. B. \& Reinsch, T. G. The Solid Phase 2.1 Bulk Density and Linear Extensibility. (2002).

36. Kjeldahl, J. Neue Methode zur Bestimmung des Stickstoffs in organischen Körpern. Z. Anal. Chem. 22, (1883).

37. Tedesco, M. J., Gianello Clésio, Bissani, C. A., Bohnen, H. \& Volkweiss, S. J. Análise de solo, plantas e outros materiais. vol. 5 (1995).

38. Brady, N. C. \& Weil, R. Elementos da Natureza e Propriedades do Solo. (2013).

39. Nommik, H. The effect of pellet size on the ammonia loss from urea applied to forest soil. Plant Soil 39, (1973).

40. Lara Cabezas, A. R., Trivelin, P. C. O., Bendassolli, J. A., de Santana, D. G. \& Gascho, G. J. Calibration of a semi-open static collector for determination of ammonia volatilization from nitrogen fertilizers. Commun. Soil Sci. Plant Anal. 30, 389-406 (1999).

41. Soares, J. R., Cantarella, H. \& Menegale, M. L. de C. Ammonia volatilization losses from surface-applied urea with urease and nitrification inhibitors. Soil Biol. Biochem. 52, 82-89 (2012). 
42. Minato, E. A. et al. Controlled-release nitrogen fertilizers: Characterization, ammonia volatilization, and effects on second-season corn. Rev. Bras. Ciênc. Solo 44, (2020).

43. R Development Core Team. A Language and Environment for Statistical Computing. (2018).

44. Palma, R. M., Saubidet, M. I., Rimolo, M. \& Utsumi, J. Nitrogen losses by volatilization in a corn crop with two tillage systems in the Argentine Pampa. Commun. Soil Sci. Plant Anal. 29, (1998).

45. Grohs, M. et al. Resposta do arroz irrigado ao uso de inibidor de urease em plantio direto e convencional. Ciênc. Agrotec. 35, (2011).

46. Badagliacca, G. et al. Long-term effects of contrasting tillage on soil organic carbon, nitrous oxide and ammonia emissions in a Mediterranean Vertisol under different crop sequences. Sci. Total Environ. 619, 18-27 (2018).

\section{Tables}

Table 1 - Regression parameters adjusted to the accumulated losses of $\mathrm{N}^{-\mathrm{NH}_{3}}$ by volatilization and maximum daily losses of the fertilizers under T system and NT system 


\begin{tabular}{|c|c|c|c|c|c|c|c|c|c|}
\hline \multirow[t]{2}{*}{ Treatment } & \multirow[t]{2}{*}{ System } & \multicolumn{4}{|c|}{ Parameters } & \multirow[t]{2}{*}{$\begin{array}{l}\text { MDL } \\
(\mathrm{kg})\end{array}$} & \multicolumn{3}{|c|}{$\begin{array}{l}\text { Time for volatilization of } 10,20 \text { and } \\
50 \% \text { of the maximum losses } \\
\text { observed for PU. }\end{array}$} \\
\hline & & a & b & k & $\mathrm{R}^{2}$ & & $10 \%$ (day) & $20 \%$ (day) & $50 \%$ (day) \\
\hline \multicolumn{10}{|c|}{ 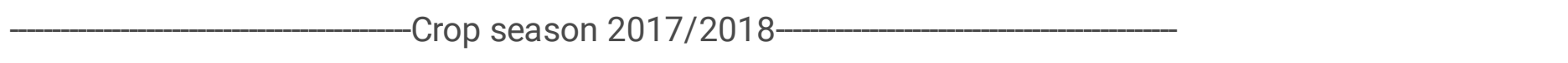 } \\
\hline \multirow[t]{2}{*}{ PU } & NT & 30.27 & 2.30 & 1.20 & 0.91 & 13.62 & 0.5 & 1.2 & 2.3 \\
\hline & $\mathrm{T}$ & 27.17 & 2.41 & 2.10 & 0.97 & 21.39 & 1.3 & 1.7 & 2.4 \\
\hline \multirow[t]{2}{*}{$\mathrm{U}_{\mathrm{CuB}}$} & NT & 29.34 & 2.59 & 0.86 & 0.91 & 9.46 & 0.1 & 1.1 & 2.6 \\
\hline & $\mathrm{T}$ & 18.16 & 3.17 & 1.01 & 0.93 & 6.87 & 1.6 & 2.4 & 4.2 \\
\hline \multirow[t]{2}{*}{$U_{\text {NBPT }}$} & NT & 24.78 & 3.31 & 0.80 & 0.89 & 7.43 & 0.9 & 2.0 & 4.0 \\
\hline & $\mathrm{T}$ & 12.13 & 5.71 & 0.36 & 0.93 & 1.63 & 2,2 & 5.1 & $\star \star$ \\
\hline \multirow[t]{2}{*}{ AS } & NT & 3.64 & 3.33 & 0.26 & 0.97 & 0.35 & - & - & - \\
\hline & $\mathrm{T}$ & 2.33 & 2.90 & 0.19 & 0.96 & 0.16 & - & - & - \\
\hline \multirow[t]{2}{*}{ AN } & NT & 1.38 & 3.97 & 0.33 & 0.96 & 0.17 & - & - & - \\
\hline & $\mathrm{T}$ & 1.49 & 3.34 & 0.36 & 0.97 & 0.20 & - & - & - \\
\hline \multirow[t]{2}{*}{ Control } & NT & 1.26 & 3.61 & 0.38 & 0.97 & 0.17 & - & - & - \\
\hline & $\mathrm{T}$ & 0.84 & 4.03 & 0.35 & 0.97 & 0.11 & - & - & - \\
\hline \multicolumn{10}{|c|}{ 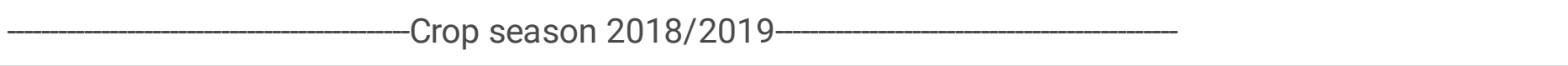 } \\
\hline \multirow[t]{2}{*}{ PU } & NT & 30.50 & 3.98 & 0.84 & 0.98 & 9.60 & 1.5 & 2,3 & 4.0 \\
\hline & $\mathrm{T}$ & 19.52 & 3.69 & 1.56 & 0.99 & 11.41 & 2.3 & 2.8 & 3.7 \\
\hline \multirow[t]{2}{*}{$\mathrm{U}_{\mathrm{CuB}}$} & NT & 29.08 & 4.98 & 0.61 & 0.98 & 6.65 & 1.7 & 2.7 & 5.0 \\
\hline & $\mathrm{T}$ & 23.98 & 4.37 & 1.18 & 0.97 & 10.61 & 2.3 & 3.0 & 4.0 \\
\hline \multirow[t]{2}{*}{$\mathrm{U}_{\mathrm{NBPT}}$} & NT & 17.70 & 8.94 & 0.95 & 0.98 & 6.30 & 7.5 & 8.3 & 11 \\
\hline & $\mathrm{T}$ & 17.02 & 8.57 & 1.26 & 0.99 & 8.04 & 7.0 & 7.6 & 9.0 \\
\hline \multirow[t]{2}{*}{ AS } & NT & 0.92 & 4.78 & 0.36 & 0.94 & 0.12 & - & - & - \\
\hline & $\mathrm{T}$ & 1.50 & 1.09 & 0.13 & 0.97 & 0.07 & - & - & - \\
\hline \multirow[t]{2}{*}{ AN } & NT & 1.18 & 2.27 & 0.15 & 0.99 & 0.06 & - & - & - \\
\hline & $\mathrm{T}$ & 0.89 & 3.90 & 0.16 & 0.98 & 0.05 & - & - & - \\
\hline \multirow[t]{2}{*}{ Control } & NT & 0.62 & 5.07 & 0.25 & 0.98 & 0.05 & - & - & - \\
\hline & $\mathrm{T}$ & 0.30 & 6.43 & 0.22 & 0.90 & 0.02 & - & - & - \\
\hline
\end{tabular}


a: Asymptotic value (percentage of maximum volatilization); b: Day when the maximum $\mathrm{N}^{-\mathrm{NH}_{3}}$ loss occurs; k: relative index and MDL (maximum daily loss); ** The maximum loss of this treatment did not reach $50 \%$ of the maximum loss for PU.

Table 2 - Accumulated losses under NT system and T system, accumulated losses, and percentage of increase in the losses under NT system relatively to T system.

\begin{tabular}{|c|c|c|c|c|c|c|c|}
\hline \multirow[t]{3}{*}{ Treatment } & \multicolumn{7}{|c|}{$\longrightarrow$ No-till— } \\
\hline & \multicolumn{2}{|c|}{$-2017 / 2018-$} & \multicolumn{2}{|c|}{$-2018 / 2019-$} & \multicolumn{3}{|l|}{--Sum-- } \\
\hline & $\begin{array}{l}\mathrm{NH}_{3}\left(\mathrm{~kg} \mathrm{ha}^{-}\right. \\
\left.{ }^{1}\right)\end{array}$ & $\begin{array}{l}\% \\
\text { Red. }\end{array}$ & $\begin{array}{l}\mathrm{NH}_{3}\left(\mathrm{~kg} \mathrm{ha}^{-}\right. \\
\left.{ }^{1}\right)\end{array}$ & $\begin{array}{l}\% \\
\text { Red. }\end{array}$ & $\mathrm{NH}_{3}\left(\mathrm{~kg} \mathrm{ha}^{-1}\right)$ & $\%$ Red. & $>\mathrm{NT} / \mathrm{T}(\%)$ \\
\hline $\mathrm{U}_{\mathrm{NBPT}}$ & $41.0 \mathrm{Ab}$ & 17 & $28.4 \mathrm{Ab}$ & 39 & $69.5 \mathrm{Ab}$ & 28 & 34 \\
\hline $\mathrm{U}_{\mathrm{CuB}}$ & $47.5 \mathrm{Aa}$ & 4 & $45.3 \mathrm{Aa}$ & 3 & $92.9 \mathrm{Aa}$ & 3 & 27 \\
\hline AN & $2.2 \mathrm{Ac}$ & 95 & 1.7 Ac & 96 & $3.9 \mathrm{Cc}$ & 96 & 5 \\
\hline AS & $5.6 \mathrm{Ac}$ & 89 & $1.5 \mathrm{Ac}$ & 97 & $7.2 \mathrm{Cc}$ & 92 & 18 \\
\hline PU & $49.3 \mathrm{Aa}$ & - & 46.8 Aa & - & $96.2 \mathrm{Aa}$ & - & 23 \\
\hline CV(\%) & 12 & - & 24 & - & 14 & - & - \\
\hline & $\longrightarrow$ & - & Till—_ & - & - & & \\
\hline $\mathrm{U}_{\mathrm{NBPT}}$ & 18.9 Bc & 57 & $27.2 \mathrm{Ab}$ & 6 & $46.1 \mathrm{Bb}$ & 37 & - \\
\hline $\mathrm{U}_{\mathrm{CuB}}$ & $29.6 \mathrm{Bb}$ & 32 & $38.4 \mathrm{Ba}$ & -28 & $68.0 \mathrm{Bb}$ & 7 & - \\
\hline AN & $2.3 \mathrm{Ad}$ & 94 & $1.4 \mathrm{Ac}$ & 95 & $3.7 \mathrm{Cc}$ & 95 & - \\
\hline AS & $3.6 \mathrm{Ad}$ & 92 & $2.3 \mathrm{Ac}$ & 92 & $5.9 \mathrm{Cc}$ & 92 & - \\
\hline PU & $43.58 \mathrm{Ba}$ & - & $29.95 \mathrm{Bb}$ & - & $73.53 \mathrm{Ba}$ & - & - \\
\hline CV(\%) & 12 & $\ldots$ & 24 & $\ldots$ & 14 & - & \\
\hline
\end{tabular}

${ }^{*} \mathrm{NH}_{3}=$ losses of $\mathrm{N}-\mathrm{NH}_{3}$ by volatilization, \% Red = percentage of reduction in the $\mathrm{N}^{-\mathrm{NH}_{3}}$ losses in relation to $\mathrm{PU},>\mathrm{NT} / \mathrm{T}=$ percentage of increase in the $\mathrm{N}^{-\mathrm{NH}_{3}}$ losses under $\mathrm{NT}$ relatively to conventional tillage. Means followed by the same upper letter do not differ between tillage systems, and lower letters do not differ between the studied sources.

Table 3 - Characteristics of the experiments performed in the 2017/2018 and 2018/2019 crop seasons 


\begin{tabular}{|c|c|c|}
\hline \multirow[t]{2}{*}{ Characteristics } & $2017 / 2018$ & 2018/2019 \\
\hline & $\begin{array}{l}\text { Medeiros, Minas Gerais State, } \\
\text { Brazil. }\end{array}$ & $\begin{array}{l}\text { Bambuí, Minas Gerais State, } \\
\text { Brazil. }\end{array}$ \\
\hline Soil type & Acrudox & Acrudox \\
\hline Latitude & $20^{\circ} 07^{\prime} 00^{\prime \prime} \mathrm{S}$ & $20^{\circ} 06^{\prime} 47^{\prime \prime} \mathrm{S}$ \\
\hline Longitude & $46^{\circ} 09^{\prime} 55^{\prime \prime} \mathrm{W}$ & $46^{\circ} 10^{\prime} 00^{\prime \prime} \mathrm{W}$ \\
\hline $\begin{array}{l}\text { Annual average temperature } \\
\left({ }^{\circ} \mathrm{C}\right)\end{array}$ & 20.3 & 21.3 \\
\hline $\begin{array}{l}\text { Average annual precipitation } \\
(\mathrm{mm})\end{array}$ & 1,457 & 1,369 \\
\hline $\begin{array}{l}\text { Acumulated precipitation }(\mathrm{mm}) \\
\text { (a) }\end{array}$ & 134.5 & 155.5 \\
\hline Total N (kg ha $\left.{ }^{-1}, 0-0.20 \mathrm{~m}\right)$ & $2,330(\mathrm{~T}) ; 2,024(\mathrm{NT})$ & $2,250(\mathrm{~T}) ; 1,765(\mathrm{NT})$ \\
\hline $\mathrm{NO}_{3}^{-}\left(\mathrm{kg} \mathrm{ha}^{-1}, 0-0.20 \mathrm{~m}\right)$ & $24.6(\mathrm{~T}), 18.7(\mathrm{NT})$ & $55.75(\mathrm{~T}), 62(\mathrm{NT})$ \\
\hline $\mathrm{NH}_{4}^{+}\left(\mathrm{kg} \mathrm{ha}^{-1}, 0-0.20 \mathrm{~m}\right)$ & $8.2(\mathrm{~T}), 27.7(\mathrm{NT})$ & $44(\mathrm{~T}), 36.5(\mathrm{NT})$ \\
\hline $\mathrm{pH}(0-0.20 \mathrm{~m})^{(\mathrm{b})}$ & $5.5(\mathrm{~T}), 5.69(\mathrm{NT})$ & $5.9(\mathrm{~T}), 5.8(\mathrm{NT})$ \\
\hline
\end{tabular}

${ }^{(a)}$ Accumulated after 29 days of fertilization ${ }^{(b)} \mathrm{pH}$ in water 1:2.5 (v/v).

Table 4 - Ammonia $\left(\mathrm{N}^{-\mathrm{NH}_{3}}\right)$ losses in no-till (NT) and till ( $\left.\mathrm{T}\right)$ till systems 


\begin{tabular}{|c|c|c|c|c|}
\hline \multirow[t]{2}{*}{ Crops } & \multirow[t]{2}{*}{ Fertilizers and $\mathrm{N}$ rates } & NT & $T$ & \multirow[t]{2}{*}{ References } \\
\hline & & \multicolumn{2}{|c|}{$\mathrm{N}-\mathrm{NH}_{3}$} & \\
\hline Corn & Urea (60 kg N ha-1) & 3 & 2.3 & 34 \\
\hline \multirow[t]{2}{*}{ Rice } & Urea & 24.8 & 0.63 & 45 \\
\hline & Coated urea $\mathrm{Cu}+\mathrm{B}\left(120 \mathrm{~kg} \mathrm{~N} \mathrm{ha}^{-1}\right)$ & 11.6 & 0.01 & \\
\hline Corn 28 years & Urea $\left(160 \mathrm{~kg} \mathrm{~N} \mathrm{ha}^{-1}\right)$ & 12.7 & 2.1 & 15 \\
\hline \multirow[t]{2}{*}{ Camelina sativa L. 20 years } & Urea & 0.51 & 0.51 & 21 \\
\hline & Urea + NBPT $\left(90 \mathrm{~kg} \mathrm{~N} \mathrm{ha}^{-1}\right)$ & 0.28 & 0.29 & \\
\hline Wheat/Wheat & Diammonium phosphate $\left(80 \mathrm{~kg} \mathrm{~N} \mathrm{ha}^{-1}\right)$ & 16.8 & 16 & 46 \\
\hline Wheat/faba bean 20 years & Urea + ammonium nitrate $\left(120 \mathrm{~kg} \mathrm{~N} \mathrm{ha}^{-1}\right)$ & 10.4 & 10 & \\
\hline \multirow[t]{2}{*}{ Corn } & Urea & 18 & - & 31 \\
\hline & Urea $+\mathrm{Cu}+\mathrm{B}\left(100 \mathrm{~kg} \mathrm{ha}^{-1}\right)$ & 11 & & \\
\hline \multirow[t]{2}{*}{ Corn } & Urea & 21.1 & - & 2 \\
\hline & Urea $+\mathrm{Cu}+\mathrm{B}\left(150 \mathrm{~kg} \mathrm{ha}^{-1}\right)$ & 17.3 & & \\
\hline \multirow[t]{2}{*}{ Corn 20 years } & Urea & 22.0 & - & 14 \\
\hline & Urea + NBPT $\left(200 \mathrm{~kg} \mathrm{ha}^{-1}\right)$ & 4.4 & & \\
\hline \multirow[t]{2}{*}{ Corn 20 years } & Urea & 26.0 & - & 4 \\
\hline & Urea + NBPT $\left(150 \mathrm{~kg} \mathrm{ha}^{-1}\right)$ & 5.4 & & \\
\hline
\end{tabular}

Table 5 - Soil organic carbon and nitrogen contents and carbon and nitrogen stocks at different soil depths in conventional tillage (T) and no-till (NT) systems in the 2017/2018 and 2018/2019 crop seasons.

Sist.: tillage system, $\mathrm{OC}=$ organic carbon, $\mathrm{TN}=$ total nitrogen, $\mathrm{C} / \mathrm{N}=$ carbon to nitrogen ratio, $\mathrm{BD}=$ bulk density determined by the core method; $\mathrm{E}_{\mathrm{NT}}=$ total nitrogen stock, $\mathrm{E}_{\mathrm{CO}}=$ organic carbon stock, $\mathrm{E}_{\mathrm{NH} 4}{ }^{+}=$ nitrogen stock as ammonium, $\mathrm{E}_{\mathrm{NO} 3}{ }^{-}=$nitrogen stock as nitrate, $\mathrm{E}_{\mathrm{NM}}=$ mineral nitrogen $\left(\mathrm{E}_{\mathrm{NH} 4+}+\mathrm{E}_{\mathrm{NO} 3}\right)$ stock.

\section{Figures}




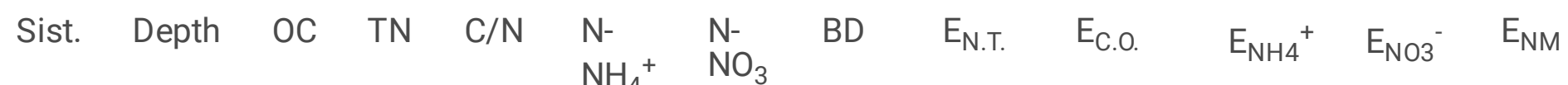

\section{7/2018 Crop season}

$\mathrm{cm} \quad-\mathrm{g} \mathrm{kg}^{-}$

$\ldots \mathrm{mg} \mathrm{dm}^{-3}-\quad \mathrm{kg}$

$-\mathrm{kg} \mathrm{ha}^{-1}$

\begin{tabular}{lllllllllllll}
$\mathrm{T}$ & $0-5$ & 17 & 2.5 & 6.8 & 13.9 & 29.0 & 0.9 & 1,125 & 7,650 & 6.6 & 13.8 & 20.4 \\
\hline
\end{tabular}

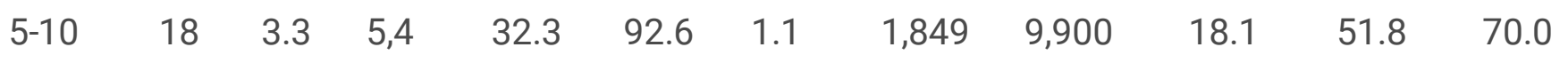

$\begin{array}{llllllllllll}10-20 & 18 & 2.8 & 6,4 & 6.6 & 14.4 & 1.1 & 3,139 & 19,800 & 3.8 & 16.4 & 20.2\end{array}$

$\begin{array}{llllllllllll}0-20 & 18 & 2.8 & 6,4 & 29.8 & 75.2 & - & 2,330 & 14,287 & 8.2 & 24.6 & 65.3\end{array}$

$\begin{array}{lllllllllllll}\text { NT } & 0-5 & 25 & 2.8 & 9,0 & 45.1 & 38.9 & 1.2 & 1,656 & 15,000 & 26.5 & 22.8 & 49.3\end{array}$

$\begin{array}{llllllllllll}5-10 & 22 & 2.1 & 10.4 & 50.8 & 13.6 & 1.2 & 1,231 & 13,200 & 29.5 & 7.9 & 37.4\end{array}$

$\begin{array}{llllllllllll}10-20 & 19 & 2.3 & 8.2 & 50.1 & 6.1 & 1.1 & 2,606 & 20,900 & 27.4 & 6.7 & 34.1\end{array}$

$\begin{array}{llllllllllll}0-20 & 21 & 2.4 & 9.0 & 98.1 & 32.3 & - & \mathbf{2}, 024 & \mathbf{1 7 , 5 0 0} & 27.7 & 18.7 & \mathbf{7 7 . 5}\end{array}$

\section{8/2019 Crop season}

\begin{tabular}{|c|c|c|c|c|c|c|c|c|c|c|c|c|}
\hline \multirow[t]{4}{*}{$\mathrm{T}$} & $0-5$ & 14 & 3.9 & 3,6 & 40.9 & 39 & 1.0 & 1,955 & 7,000 & 21 & 19 & 40 \\
\hline & $5-10$ & 16 & 2.9 & 5,5 & 141 & 81 & 1.0 & 1,465 & 8,000 & 69 & 40 & 109 \\
\hline & $10-20$ & 14 & 2.8 & 5,0 & 42.2 & 80 & 1.0 & 2,790 & 7,000 & 43 & 82 & 125 \\
\hline & $0-20$ & 14 & 3.1 & 4,5 & 66.6 & 71 & - & 2,250 & 7,250 & 44 & 55.75 & 274 \\
\hline \multirow[t]{4}{*}{ NT } & $0-5$ & 21 & 2.2 & 9,5 & 35.8 & 67 & 1.0 & 1,450 & 10,500 & 18 & 34 & 52 \\
\hline & $5-10$ & 16 & 1.9 & 8,4 & 75.8 & 80 & 1.1 & 1,050 & 8,800 & 42 & 44 & 85 \\
\hline & $10-20$ & 11 & 1.9 & 6,0 & 36.5 & 72 & 1.2 & 2,280 & 13,200 & 43 & 85 & 128 \\
\hline & $0-20$ & 15 & 2.0 & 7,5 & 51.2 & 81 & - & 1,765 & 11,425 & 36.5 & 62 & 265 \\
\hline
\end{tabular}




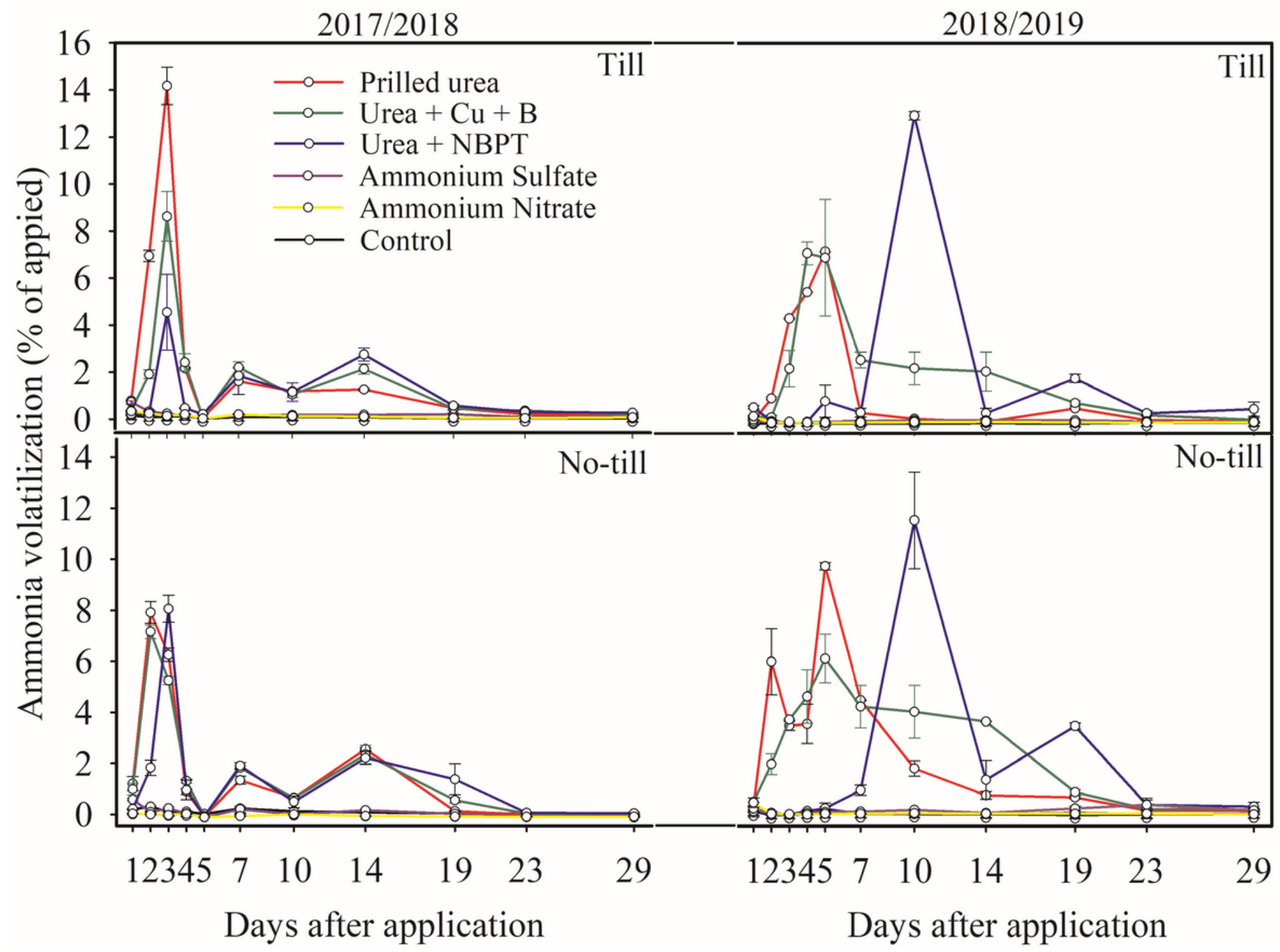

Figure 1

Daily losses of N-NH3 of the fertilizer sources applied as top dressing during corn cultivation in the 2017/2018 and 2018/2019 crop seasons, in conventional tillage (T) and no-till (NT) systems. 


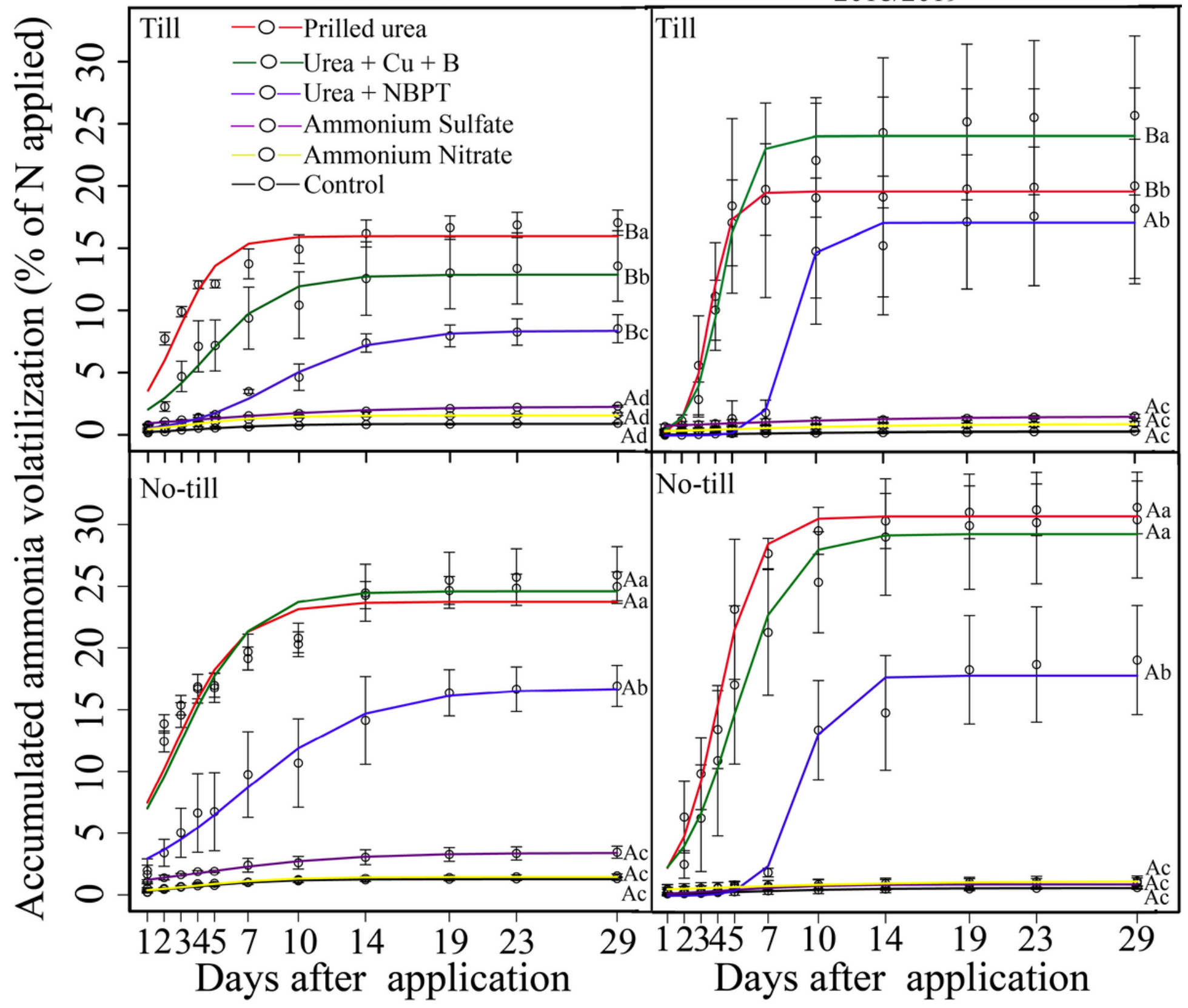

Figure 2

Accumulated losses of N-NH3 by volatilization per fertilizers applied as top dressing fertilization of corn in the 2017/2018 and 2018/2019 crop seasons, under conventional tillage (T) and no-till (NT) systems. Means followed by the same upper letter (tillage system) and lower letter (sources of $\mathrm{N}$ fertilizer) do not differ at $5 \%$ significance level by the Scott-Knott test 


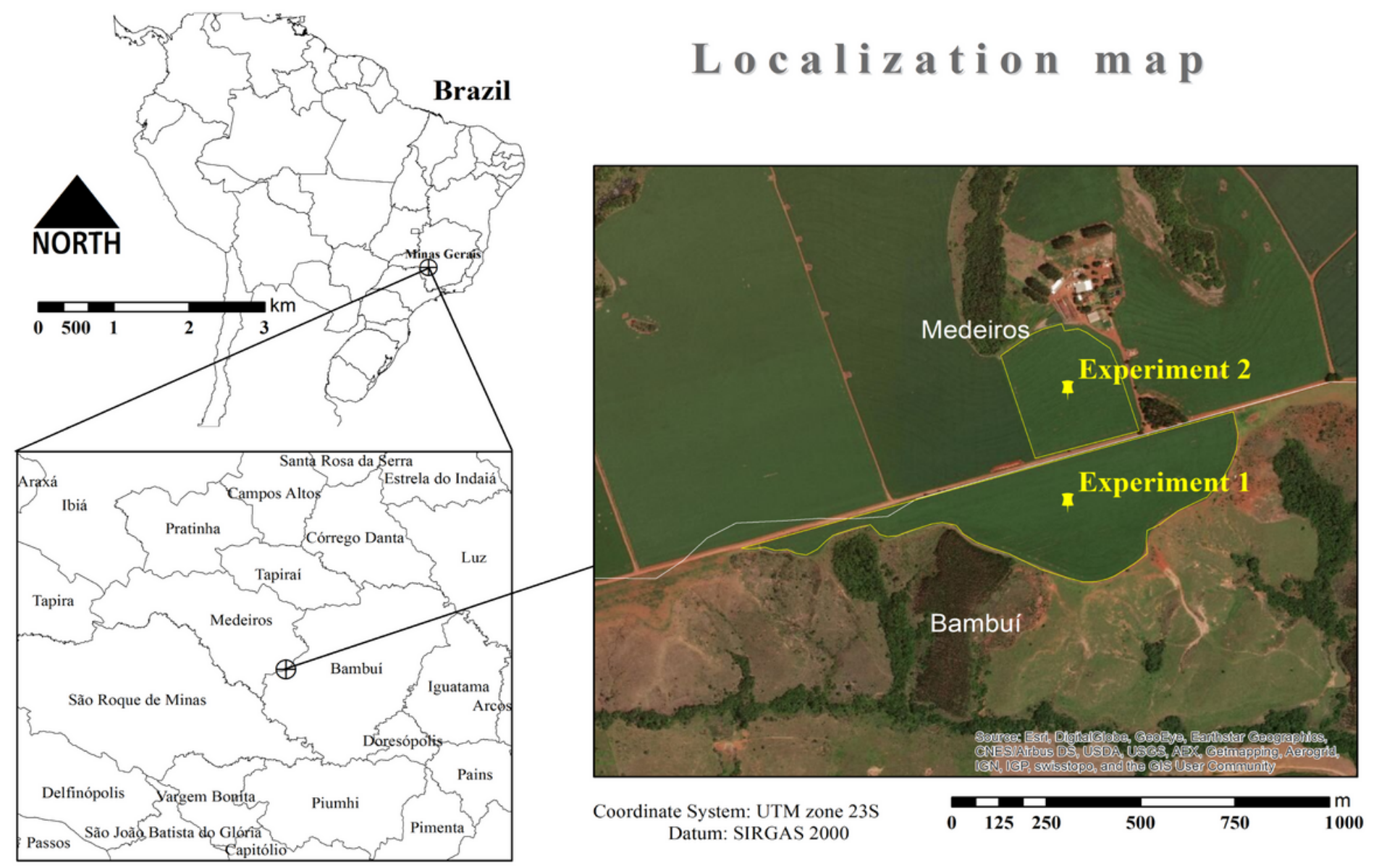

\section{Figure 3}

Location of the experimental areas, Experiment 1 (crop season 2017/2018) and Experiment 2 (crop season 2018/2019).

\section{Supplementary Files}

This is a list of supplementary files associated with this preprint. Click to download.

- SM.pdf 